Sanja Berčnik

Pedagoška

fakulteta

Univerze v

Ljubljani

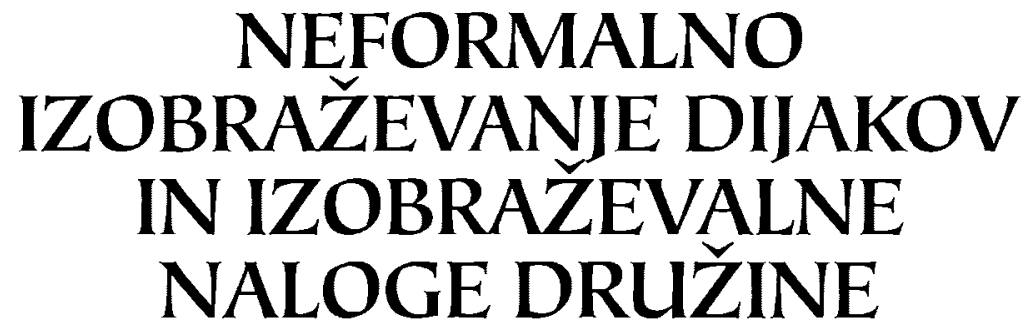

»Fant se je učil, pa ni vedel, da se uči. In je delal, pa ni vedel, da dela.« F. Milčinski (Skavt Peter)

\title{
POVZETEK
}

Avtorica v prispevku govori o pomenu neformalnega izobraževanja za mlade in njihove družine, o razlikah glede preživljanja prostega časa ter o možnostih izkoriščanja prostega časa za neformalno učenje. Izhaja iz predpostavke, da z naraščajočim obsegom izobraževanja naraščajo tudi izobraževalne naloge družine. Zaradi različnosti kulturnih okolij, iz katerih te izhajajo, pa se pojavlja vprašanje, kakšne so dejanske možnosti za neformalno učenje v njihovem domačem okolju in kako to okolje vpliva na njihov razvoj. Bistveno vprašanje, ki si ga po njenem mnenju moramo zastaviti, je, ali se starši zavedajo vpliva svojih dejanj na razvojno in izobraževalno pot svojih otrok.

Ključne besede: formalno in neformalno izobraževanje, družina, kakovost preživljanja prostega časa

\section{FORMALNO IN NEFORMALNO}

Razvoj sodobnega sveta vse bolj poudarja sposobnost posameznika, da se nenehno prilagaja hitrim spremembam, saj spreminjajoča se ekonomska, tehnološka in socialna okolja zahtevajo nove veščine, znanje in fleksibilnost. Pogoj za večanje učinkovitosti sodobnih družb in s tem tudi njenih članov je tako pospešen razvoj človeških virov, pri katerem dobiva vse večjo vlogo vseživljenjsko učenje (Memorandum, 2000, str. 3). Nekateri sicer uporabljajo izraz vseživljenjsko izobraževanje, vendar ga ne smemo izenačevati $z$ vseživljenjskim učenjem, saj se izobraževanje nanaša na sistematično in načrtno učenje (kot samoizobraževanje ali pa izobraževanje po programih formalnega ali neformalnega izobraževanja), učenje pa zajema tudi vse oblike priložnostnega učenja, neformalnega izobraževanja in učenja z izkušnjami. Oba pojma se nanašata tako na mlade kot tudi na odrasle in predstavljata koncept in osnovo za razvoj izobraževalnega sistema v celoti (Muršak, 2002, 
str. 158). OECD definira vseživljenjsko učenje kot pogled na učenje, ki obsega individualni in družbeni razvoj vseh vrst in vseh oblik formalno $v$ šolah, organizacijah za poklicno izobražcvanje, institucijah terciarnega izobraževanja in izobraževanja odraslih, in neformalno doma, na delu in v skupnosti. Gre torcj za odprt sistem, v katerem so $v$ ospredju standardi znanja in spretnosti, ki jih potrebujejo vsi, ne glede na starost. Prvotni koncept stalncga izobraževanja se je razširil in obsega še priložnostno učenje (Vseživljenjsko učenje, 2002, str. 9).

Če takole na hitro razmislimo, vsi vemo, kaj pomeni formalno in kaj neformalno izobraževanje - formalno izobraževanje se dogaja $v$ šoli, neformalno pa $v$ ustanovah zunaj nje. Vendar v resnici ni natančno tako. Poglejmo uradni definiciji obeh. Unescova opredelitev je najprej $v$ formalno izobraževanje zajela izobraževalne programe, ki zahtevajo vpis in registracijo učencev, vendar pa se je kasneje, zaradi nerodne uporabe besede vpis (vpišemo se tudi na kuharski tečaj, op. avtorice) spremenila $v$ mizobraževanje, ki naj privede do neke vrste uradno formalno potrjenih izobraževalnih rezultatov, kot so dosě̌ena stopnja izobrazbe, diploma ali poklicna kvalifikacija« (Jelenc, 1991, str. 30). Č pogledamo novejše dokumente, vidimo, da se sedaj pojavlja predvsem splošno sprejeta Unescova definicija, ki formalno izobraževanje definira kot whierarhično strukturiran, kronološko stopenjsko normiran izobraževalni sistem, ki poteka vse od primarnih do terciarnih institucij« (Cepin, 2004, str. 8).

Ko takole prebiramo značilnosti obeh vrst izobraževanja, vidimo, da skupaj tvorita nekakšno celoto, in lahko zaključimo, da sta formal-
Pogoj za večanje ucinkovitosti sodobnih družb je pospešen razvoj cloveških virov. no in neformalno izobraževanje komplementarna. Boljši izobraževalni sistem bomo torej dobili le s krepkejšo povezavo obeh oblik in z usmeritvijo vsch aktivnosti dela $z$ mladimi $v$ proces vseživljenjskega učenja posameznika. $\checkmark$ nadaljevanju nas bo zanimalo predvsem neformalno izobraževanje oziroma priložnostno izobraževanje, kjer gre za proces, ki poteka vse življenje in pri katerem vsak oblikuje stališča, pridobiva vrednote, spretnosti in znanje iz vsakodnevnih izkušenj, izobraževalnih vplivov in virov v svojem okolju, v družini, soseski, pri delu in igri, pri nakupovanju, v knjižnici in iz javnih občil (Jelenc, 1991, str. 54). Gre torej za proces, ki poteka vsak dan, vprašanje pa je, ali se tega zavedamo ali ne.

V primerjavi s formalnim izobraževanjem je neformalno izobraževanje mnogo težje defini-
rati. Pojem neformalno izobraževanje je vpeljal Philip Coombs leta 1968. Zanj je ta pojem po-
menil vsako organizirano izobraževalno dejavnost zunaj formalnega sistema izobraževanja,
ki je namenjena izbranim učencem in zadovoljuje določene učne smotre. Kot sem že omenila,
je težko podati eno splošno definicijo neformalnega izobraževanja, saj različne organizacije
to vrsto izobraževanja pojmujejo različno, kar je seveda povezano tudi z njihovim načinom
dela. V literaturi tako lahko zasledimo tudi definicijo, ki neformalno izobraževanje pojmu-
je kot strukturirano, sosledičıo organizirano izobraževanje, ki ni namenjeno pridobivanju
formalnega izkaza, ampak je namenjeno zadovoljitvi nekaterih drugih, navadno posrednih
potreb in interesov. Neformalno izobraževanje pa označujejo tudi kot izobraževanje po pro-
gramih, ki ne zahtevajo ali pa ne predpisujejo uradnega vpisa ali registracije učencev (Jelenc,
199l, str. 46-57). 


\section{OPREDELITEV PROBLEMA}

$\mathrm{V}$ pričujočem besedilu bomo pozornost namenili posamezniku znotraj neformalnega izobraževanja. Zanimala nas bo mladina, njihove družine in njihovo preživljanje prostega časa.

Vse družine niso $v$ enaki meri kos novim izobraževalnim nalogam. Tako so otroci, ki

\section{Z narašăajočim obsegom izobraževanja naraščjo tudi izobraževalne naloge družine.}

prihajajo iz kulturno manj spodbudnih okolij, prikrajšani za marsikatero pomembno izkušnjo, s selektivnim šolskim sistemom pa imajo še dodatno zaprte socialne možnosti, kar še poglablja socialne razlike med ljudmi. Največje razlike med prebivalstvom nastajajo ravno na prehodu $v$ srednjo šolo. Otroci s slabšim učnim uspehom na koncu obveznega šolanja največkrat nimajo možnosti za primeren razvoj, ne znajo se samostojno učiti in prilagajati spremembam. To jih dodatno potiska $v$ položaj socialne izločenosti, saj v poklicnih šolah manjkajočih sposobnosti ne morejo razviti. Sodobni način življenja terja od posameznika nenehno prilagajanje, kar pa seveda zahteva nepretrgan proces ǔenja in izpopolnjevanja. Vse bolj se torej uveljavlja t. i. »učeča se družba«, v kateri nam zasebno in družbeno življenje (lahko) ponujata vse več priložnosti za (predvsem neformalno) učenje in izobraževanje. Potrebno se je namreč zavedati in o tem osvestiti tudi

\section{Mladost je tvegano obdobje za prido- bitev socialnega položaja $v$ družbi.}

mlajše generacije, da je učenje lahko tudi zabavno, da poteka (tudi) $v$ družini, $v$ prostem času, v skupnosti in pri vsakdanjih opravilih. Še posebej je neformalno izobraževanje pomembno v obdobju mladosti oziroma v prehodnem obdobju k odraslosti. Gre namreč za obdobje, v katerem posameznik oblikuje svojo osebnost na osnovi dispozicij in interakcije s socialnim in fizičnim okoljem.
Ne glede na to, kako različna so mnenja avtorjev o časovni razmejitvi tega obdobja, pa so skladna o tem, da $v$ tem obdobju mladostnik opravlja vrsto bolj ali manj težavnih razvojnih nalog. $V$ tem obdobju posameznik išče lastno identiteto, oblikuje se njegov odnos do lastnega telesa in spolne vloge, odnosi z vrstniki, starši in drugimi avtoritetami, odnos do prihodnosti, zlasti do študija, poklica, dela in družine, poteka pa tudi prilagajanje družbene- mu okolju, ki zajema socialno odgovorno vedenje, ustrezen vrednotni sistem in lastna moralna načela. Bistveni del socialnega statusa mladostnikov je vezan na življenjske perspektive $v$ prihodnosti. Predvsem od položaja v širši družbi je odvisno, ali imajo mladi občutek perspektivnosti ali ne. Mladost je rizično obdobje ne samo zaradi tveganj, povezanih z oblikovanjem lastne identitete, ampak tudi zaradi tveganj, povezanih $s$ pridobitvijo socialnega položaja $v$ družbi. Nedoločenost meje med mladostjo in odraslostjo je povezana $z$ vse večjo »individualizacijo m mladosti. Posameznikom je $v$ vse večji meri prepuščeno, da sami določajo glavna vodila svojega življenja (kdaj in kako bodo vstopili v delovni proces, kdaj, in če sploh, se bodo odločili za družino, kako bodo izkoriššali svoj prosti čas ...) (Horvat, 1987).

Skozi raziskavo, ki smo jo poimenovali »Mladi in prosti čas ${ }_{3}$ bomo poskušali ugotoviti, kaj mladi počnejo v prostcm času in kako to počnejo, kakšne so možnosti za (neformalno) učenje $v$ njihovem domačem okolju (ožjem, tj. družina, in širšem, tj. soseska). Za otroka je namreč izredno pomembno, da mu starši omogočijo spoznavati različne načine preživljanja prostega časa in različne načine učenja, da ima na primer možnost priti v stik z dobrimi knjigami. Možnosti neformalnega učenja v družini segajo na različna področja vsakodnevne aktivnosti, preživljanje prostega časa, socialni stik z okolico, komunikacija z družinskimi člani in seveda odnos do novih informacij, izobraževanja in medijev. Tako se 
A. Krajnc opozarja, da je tisto, na kar morajo biti starši v tem obdobju še posebej pozorni, dejstvo, da čeprav svojih otrok posebej ne učijo, se določeno znanje in informacije spontano pretakajo med njimi in otroki $v$ družinski komunikaciji $-v$ pogovorih, $v$ interesnih dejavnostih, na izletih, nasploh v življenjskem stilu, ki ga družina živi (Krajnc, 1995, str. J29-130). V družini torej pridobivamo različne informacije, podatke, spoznanja, navade, razvade, učimo se socialnega vedenja, vzorcev komunikacije, oblikujemo si interese, vrednote in razvijamo svoje sposobnosti. Vir učenja $v$ družini predstavljajo predvsem medosebni odnosi in skupne dejavnosti. Učenje se odvija ob konkretnih dejavnostih - vsakodnevnih opravilih, dejavnostih v prostem času. Družinsko učenje naj bi torej potekalo kot prostovoljno medsebojno vplivanje pri vseh družinskih aktivnostih, kjer družinski člani povezujejo svoje vsakodnevne izkušnje in refleksijo $z$ določenim ciljem ter tudi $z$ uporabo različnih virov (Ličen, 1996, str. 2-5).

bomo usmerili predvsem na kvaliteto preživljanja prostega časa, za katero menimo, da je v veliki meri odvisna tudi od staršev. Zanimalo nas bo, kaj lahko mladostniku $v$ sklopu vseživljenjskega učenja nudi družina, kajti kot vemo, se družine razlikujejo med seboj glede pripadnosti različnim slojem v družbi, kjer so materialni in socialni viri različni, razlikujejo pa se tudi glede na kulturo, v kateri živijo (Ličen, 2001, str. 32-37). Med družinami torej obstajajo razlike in slovenske raziskave so pokazale soodvisnost med razvojem otro$\mathrm{ka}$, šolskimi dosežki in okoljem, v katerem otrok Živi. Vpliv staršev je viden predvsem v razvijanju kulture učenja, pri čemer ima neformalno izobraževanje bistveno funkcijo. Razlike med vplivi družine pa postanejo še posebej vidne $v$ obdobju mladostništva, ko se dogaja enkraten in nepovraten proces umeščanja posameznika $v$ različne življenjske oblike (Ule, 1995, str. 13-14). K problemu preživljanja prostega časa mladine smo se usmerili predvsem zato, ker menimo, da se mladina ne zaveda, kaj vse se (lahko) nauči v prostem času, predvsem zaradi tega, ker pojem učenje preozko povezuje le z šolo. Prav tako menimo, da starši ne namenijo dovolj pozornosti kvaliteti preživetega prostega časa - tako svojega kot tudi svojih otrok. Večina družinskega neformalnega izobraževanja se namrcč dogaja $v$ prostem času, zato je pomembno, da družinski člani kritično in odgovorno izbirajo prostočasne dejavnosti. Informacije in priložnosti za učenje namreč niso vsem enako dostopne, pri tem pa ima družina tako pomembno vlogo, da njenega vpliva ni mogoče zanemariti. Družina je torej socialno okolje, ki najbolj vpliva na razvoj posameznika, saj je prva in najmočnejša šola življenja za otroke. Znotraj družine se v kontekstu medosebnih odnosov oblikujejo predispozicije za vseživljenjsko izobraževanje. V pričujoči raziskavi bomo iskali povezavo med prežjvljanjem prostega časa staršev in otrok, povezavo med izobrazbo staršev in kvaliteto preživetega prostega časa, zanimala pa nas bo predvsem razlika $\vee$ kvaliteti preživljanja prostega časa med dijaki gimnazije in dijaki poklicne šole. Dandanes vse (pre)več otrok svoj prosti čas preživlja le pred televizorjem ali računalnikom. To sicer ni samo po sebi slabo, ampak je odvisno predvsem od tega, kaj gledajo oziroma delajo $v$ tem času.

\section{METODOLOŠKI OKVIR RAZISKAVE}

Pred začetkom raziskovalnega dela smo postavili naslednje hipoteze:

Otroci bolj izobraženih staršev kvalitetneje preživljajo svoj prosti čas (več berejo, obiskujejo razstave, prireditve ...).

Otroci in njihovi starši preživljajo prosti čas na podoben način. 
Dijaki, ki doma »obravnavajo« javne (kulturne, politične, ekonomske ...) teme, te »obravnavajo tudi $v$ pogovorih $\mathrm{s}$ prijatelji.

Dijaki, vpisani na poklicno šolo, imajo ožje interese (ne hodijo na razstave, prireditve, ne berejo časopisov, ne spremljajo javnih dogodkov ...).

Preživljanje prostega časa dijakov poklicnih šol je bolj monotono kot preživljanje prostega časa dijakov gimnazije.

Dijaki gimnazije imajo doma več možnosti za neformalno učenje (doma imajo naročen časopis oziroma ga kupujejo, več hodijo na izlete, spoznavajo druge kraje, doma obravnavajo tudi razne javne teme, njihovo mnenje $v$ pogovoru je upoštevano, znajo poiskati informacije ...).

Starši gimnazijce bolj spodbujajo k iskanju znanja.

Dijaki poklicnih šol in njihovi stars̆i živijo v ožjem krogu ljudi (na obiske hodijo redko oziroma se družijo $z$ ozkim krogom ljudi, ponavadi v domačem kraju).

Na podlagi hipotez smo oblikovali anketna vprašanja. Raziskava je bila opravljena na šolskem centru Celje v dveh razredih triletne poklicne šole, in sicer gradbene smeri, ter na

\section{Ali otroci bolj izobraženih staršev kvalitet- neje preživljajo prosti čas?}

I. gimnaziji $v$ Celju $v$ dveh razredih splošne gimnazije. $V$ vzorec smo zajeli vsakega drugega dijaka $v$ naključno izbranem razredu, tako da je bilo v vzorec zajetih skupaj 50 dijakov, od tega 25 iz poklicne šole in 25 iz gimnazije.

Podatke smo zbrali $z$ anonimnim anketnim vprašalnikom, $\mathrm{ki}$ je bil sestavljen iz 20 vprašanj, od tega je bilo 17 vprašanj zaprtega tipa, 6 vprašanj kombiniranega tipa (zaprto vprašanje $\mathrm{z}$ možnostjo pisanja lastnega odgovora) in 2 vprašanji odprtega tipa. $\mathrm{V}$ vprašalnik smo zajeli nekatere prostočasne dejavnosti dijakov in njihovih staršev, za katere menimo, da vplivajo na neformalno pridobivanje znanja. V nadaljevanju bomo pred- stavili rezultate raziskave Mladi in prosti $\check{c} a s$, opravljene aprila 2006.

\section{REZULTATI RAZISKAVE}

$\mathrm{V}$ raziskavi smo torej ugotavljali, ali obstajajo razlike med družinami v preživljanju prostega časa in $s$ tem $v$ možnostih neformalnega učenja glede na formalno izobrazbo staršev in predvsem glede na tip šole.

\section{IZOBRAZBA STARŠEV}

Najprej nas je zanimalo (tabela 1), kakšno izobrazbo imajo starši dijakov, kajti iskali smo povezavo med izobrazbo staršev in izobrazbeno potjo dijakov. Iz dobljenih podatkov je razvidno, da imajo starši dijakov poklicne šole $v$ povprečju nižjo izobrazbo kot starši gimnazijcev. Največ staršev dijakov poklicne šole ima po pričakovanju prav tako končano poklicno šolo ( 52,9 odstotka), med starši gimnazijcev pa jih ima največ končano splošno ali strokovno šolo (28,1 odstotka), tem pa tesno sledijo tisti, ki imajo končano visoko šolo (25 odstotkov). Med dijaki poklicne šolc nima nihče od staršev končane višje šole, ima pa 23,5 odstotka staršev končano le osnovno šolo. Na podlagi pričujočih rezultatov lahko rečemo, da otroci sledijo staršem pri njihovi izobraževalni poti oziroma izobrazba staršev vpliva na izbiro srednje šole otrok.

Bolj kot izobrazba nas je zanimalo, ali bolj izobraženi starši kvalitetneje preživljajo prosti čas in kako to vpliva na preživljanje prostega časa in s tem neformalno izobraževanje dijakov $v$ prostem času. Menimo namreč, da so starši z nižjo izobrazbo zaposleni na delovnih mestih, ki ne spodbujajo dovolj nenehnega učenja in razvoja ter $s$ tem še dodatno krepijo njihov šibek socialni status. Pri jjudeh $s$ prenizko stopnjo znanja novo znanje velikokrat naleti na "neplodna s ta in se ne more spojiti z že obstoječimi informacijami. Kot smo že omenili, se večina neformalnega 
Tabela 1: Izobrazba staršev (v odstotkih)

\begin{tabular}{|l|c|c|c|c|c|c|c|}
\hline & $\begin{array}{c}\text { končana } \\
\text { Oš }\end{array}$ & $\begin{array}{c}\text { končana } \\
\text { sred. pokl. } \\
\text { šola }\end{array}$ & $\begin{array}{c}\text { končana } \\
\text { spl./strok. } \\
\text { šola }\end{array}$ & $\begin{array}{c}\text { končana } \\
\text { višja šola }\end{array}$ & $\begin{array}{c}\text { končana } \\
\text { visoka šola }\end{array}$ & $\begin{array}{c}\text { ostalo } \\
\text { (mag., } \\
\text { dokt.) }\end{array}$ & skupa \\
\hline $\begin{array}{l}\text { starši } \\
\text { gimnazijcev }\end{array}$ & 0 & 28,1 & 28,1 & 15,6 & 25 & 3,2 & 100 \\
\hline $\begin{array}{l}\text { starši dijakov } \\
\text { pokl. šole }\end{array}$ & 23,5 & 52,9 & 17,7 & 0 & 5,9 & 0 & 100 \\
\hline
\end{tabular}

izobraževanja $v$ družini dogaja $v$ prostem času, zato je zelo pomembno, katere dejavnosti takrat izbirajo dijaki in njihovi starši.

\section{PROSTI ČAS}

$\mathrm{Na}$ grafu 1 lahko vidimo primerjavo $\mathrm{v}$ preživljanju prostega časa med dijaki gimnazije in poklicne šole ter njihovimi starši. Podatki kažejo, da največ dijakov gimnazije $\mathrm{v}$ prostem času gleda televizijo ( 20 odstotkov), prav tako to počne največ staršev gimnazijcev (23,5 odstotka) in staršev dijakov poklicne šole (31,6 odstotka). Dijaki poklicne šole pa se v prostem času največ družijo s prijatelji
(19,3 odstotka) ali pa so športno aktivni (19,3 odstotka). Zanimiva je tudi ugotovitev, da dijaki poklicne šole $v$ prostem času več berejo knjige ( 7,2 odstotka), medtem ko so med gimnazijci bolj priljubljene revije (11,4 odstotka). Večja razlika je vidna pri uporabi interneta - gimnazijci 17,1 odstotka, dijaki poklicne šole 8,4 odstotka. Tu seveda velja opozoriti na vpliv socialnih razlik med družinami - mnogi doma verjetno nimajo interneta in računalnika, predvsem tisti, katerih starši imajo nižjo izobrazbo in posledično tudi »slabšo« službo. Razlog za »manjšo « uporabo interneta se torej lahko skriva tudi tukaj. Enaka razlika se vidi tudi pri starših, kjer

\section{Graf 1: Preživlianje prostega časa dijakov gimnazije in pokliene šole ter njihovih staršev}

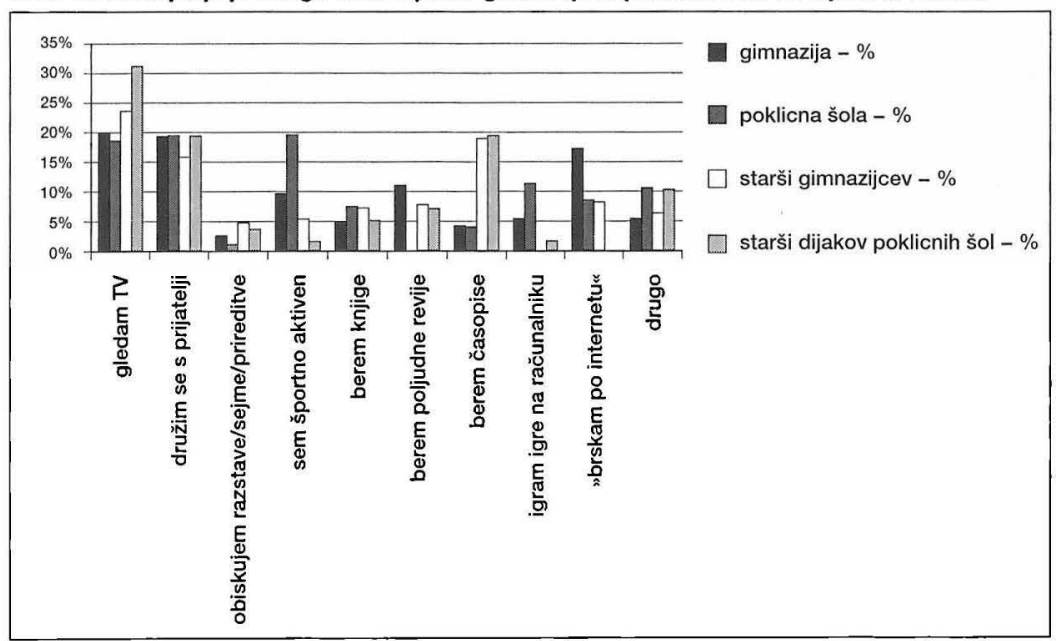


8,23 odstotka staršev gimnazijcev v prostem

času uporablja internet, medtem ko ga starši

Starši imajo

ključno vlogo pri

razvijanju zdravega in kritičnega odnosa do medijev.

dijakov poklicne šole sploh ne uporabljajo. Pri vseh starših pa se je na drugem mestu pojavilo branje časopisov. Na podlagi teh odgovorov torej težko trdimo, da bolj izobraženi starši (v tem primeru starši gimnazijcev) bolj kvalitetno preživljajo prosti čas. Natančnejši odgovor bomo poskušali dobiti pri naslednjih vprašanjih, ki prosti čas podrobneje obravnavajo.

Ker je televizija dandanes množični medij, brez katerega skorajda ne gre več, smo že vnaprej predvidevali, da bo odgovor o gledanju televizije med pogostejšimi. V nadaljevanju smo tako zastavili vprašanji, kaj gledajo po televiziji dijaki in kaj njihovi starši. Želeli smo namreč potrditi povezavo, da otroci gledajo podobne stvari kot njihovi starši.

Ugotovili smo, da dijaki gimnazije največ gledajo nadaljevanke in filme, dijaki poklicne šole pa šport. Pri starših se je izkazalo, da oboji največkrat gledajo poročila, vidna razlika pa je pri gledanju oddaj o javnih dogodkih (te oddaje gleda 22,3 odstotka staršev gimnazijcev in le 15,8 odstotka staršev dijakov poklicnih šol) in pri gledanju izobraževalnih oddaj, ki jih večkrat gledajo gimnazijci in njihovi starši. $\mathrm{Na}$ grafu 2 vidimo, da gimnazijci niso tako kritični pri izbiri vsebin, kot bi bilo pričakovati, pokaže se celo, da več dijakov poklicnih šol gleda poročila (16,2 odstotka). Lahko torej rečemo, da obstaja nekakšna povezava med vsebinami, ki jih gledajo starši, in vsebinami, ki jih gledajo dijaki, vendar bi tu poudarili, da je ta povezava vidna zgolj na osnovi neselektivnega gledanja televizije. Prav tako smo ugotovili, da dijaki gimnazije gledajo televizijo povprečno $2-4$ ure na dan, kar samo potrjuje dejstvo, da res večino prostega časa preživijo pred televizijo, dijaki poklicne šole pa so odgovore razdelili enakomerno med 2-4 ure dnevno in redko, kar dopolnjuje njihove prejšnje odgovore, da so v prostem času največkrat športno aktivni. Ker pa seveda televizija ni edini medij, nas je zanimalo tudi, ali imajo doma naročen časopis oziroma katere časopise kupujejo dijaki in njihovi starši. Ugotovili smo, da imajo pri 60 odstotkih gimnazijcev in 44 odstotkih dijakov poklicnih šol doma naročen časopis, najpogosteje gre za Novice. Zasledili smo raznovrstnost pri naročanju časopisov in

Graf 2: Gledanost programov - primerjava med dijaki in starši

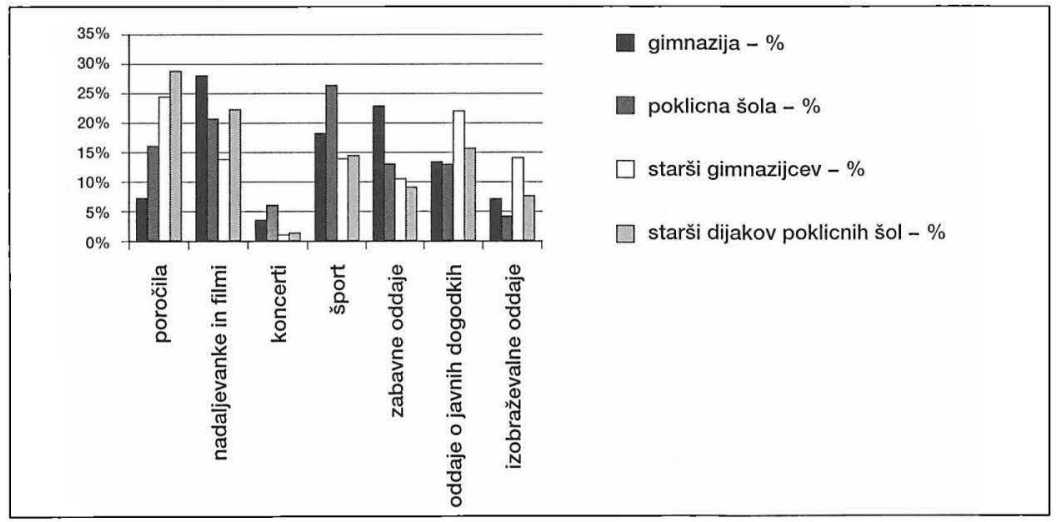


njihovem kupovanju. V obeh primerih so prisotni tudi izobraževalni časopisi oziroma revije (gimnazijci - Finance, Dnevnik, Delo; dijaki poklicnih šol - Delo, Obrtnik, Moje malo podjetje, Mavrica, Ognjišče ...). Zaradi splošne razgledanosti dijakov nas je zanimalo tudi, ali so že kdaj brali časopis Delo, in ugotovili smo, da so ga večinoma brali že vsi, razmerje pa gre rahlo $v$ prid gimnazijcem. V zvezi $\mathrm{z}$ bralnimi navadami nas je zanimalo še, kako pogosto dijaki obiskujejo knjižnice. Pri vprašanju, kako pogosto obiskujejo šolsko knjižnico (graf 3), smo presenetljivo ugotovili, da je gimnazijci v največji meri ne obiskujejo (36 odstotkov) oziroma jo obiskujejo redko (28 odstotkov) v primerjavi z dijaki poklicne šole, ki jo obiskujejo redko (36 odstotkov) oziroma takrat, ko potrebujejo literaturo za kakšno seminarsko nalogo (16 odstotkov). Pri obiskovanju drugih knjižnic pa je slika popolnoma drugačna. Izkazalo se je, da gimnazijci druge knjižnice obiskujejo pogosto (36 odstotkov) v nasprotju $z$ več kot polovico anketiranih dijakov poklicne šole, ki jih največkrat ne obiskujejo (56 odstotkov). Rezultate lahko torej interpretiramo v prid gimnazijcem, kajti obiskovanje drugih knjižnic kaže na njihovo povečano zanimanje za različno literaturo, kar je zelo pomembno, saj se doseganje višjih ravni pismenosti povezuje s pogostejšim branjem knjig, časopisov, revij, pa tudi s spremljanjem javnih dogodkov, obiskovanjem raznih kulturnih prireditev ...

Ker je mladostništvo obdobje, kjer se oblikujejo posameznikovi interesi, ki vplivajo na kvaliteto nadaljnjega življenja, si poglejmo tudi, kako pogosto dijaki obiskujejo razne razstave, kako pogosto hodijo $\mathrm{z}$ družino na obiske in potovanja, kaj se pogovarjajo doma in kaj s prijatelji.

$\mathrm{Na}$ vprašanje, kako pogosto se udeležijo kakšne razstave, so dijaki obeh tipov srednjih šol odgovarjali podobno, in sicer da jih obiskujejo redko, pokazal pa se je presenetljiv podatek, da jih 8 odstotkov dijakov poklicnih šol obiskuje redno. Nadalje nas je zanimalo, kakšne socialne stike imajo dijaki in njihovi starši z okolico. Ugotovili smo (tabela 2), da dijaki in njihovi starši na obiske hodijo nekajkrat mesečno, pri tem pa največkrat obiskujejo sorodnike.

Prva opazna razlika se je pokazala šele pri vprašanju, kam odhajajo $z$ družino na obiske. Izkazalo se je, da gimnazijci največ potujejo $v$ sosednje države (52 odstotkov), medtem ko se dijaki poklicnih šol bolj držijo okolice

\section{Graf 3: Primerjava obiskovanja knjižnic}

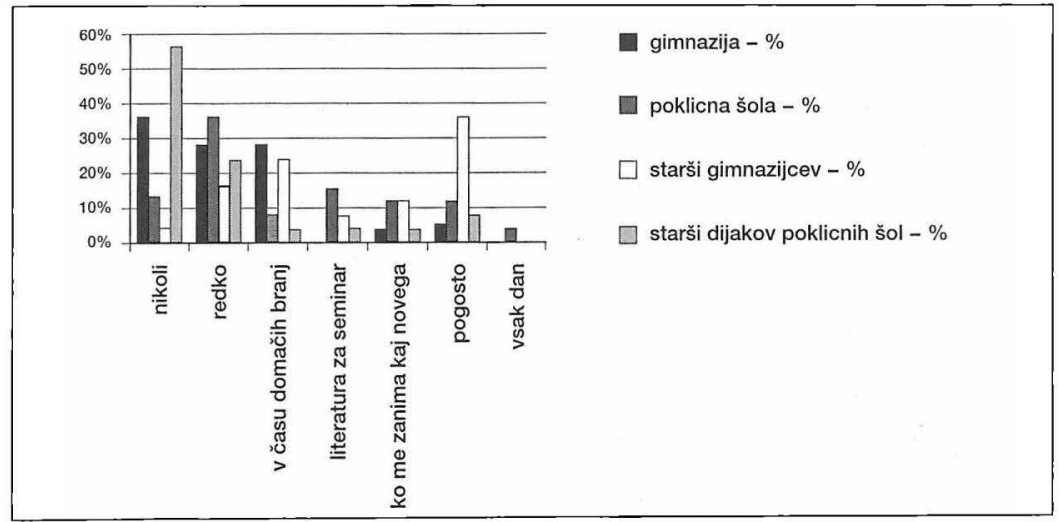


Tabela 2: Kako pogosto hodite na obiske (v odstotkih)

\begin{tabular}{|l|c|c|c|c|c|c|}
\hline & ne hodimo & $\begin{array}{c}\text { ob posebnih } \\
\text { priložnostih }\end{array}$ & $\begin{array}{c}\text { nekajkrat } \\
\text { letno }\end{array}$ & $\begin{array}{c}\text { nekajkrat } \\
\text { mesečno }\end{array}$ & $\begin{array}{c}\text { nekajkrat } \\
\text { tedensko }\end{array}$ & skupaj \\
\hline gimnazijci & 0 & 28 & 8 & 52 & 12 & 100 \\
\hline dijaki pokl. šole & 0 & 12 & 16 & 48 & 24 & 100 \\
\hline
\end{tabular}

Tabela 3: Kdo vas ponavadi obiskuje (v odstolkih)

\begin{tabular}{|l|c|c|c|c|c|}
\hline & sosedje & sorodniki & prijatelji & $\begin{array}{c}\text { sodelavei } \\
\text { staršev }\end{array}$ & skupaj \\
\hline gimnazijci & 16,7 & 41,7 & 35,4 & 6,2 & 100 \\
\hline dijaki pokl. šole & 28,9 & 47,4 & 21,4 & 2,6 & 100 \\
\hline
\end{tabular}

domačega kraja (36 odstotkov). Ta podatek žal ni spodbuden, kajti $z$ ožjim socialnim krogom so dijaki poklicnih šol prikrajšani za nekatera socialna izkustva. Zanimalo nas je še, kako pogosto imajo obiske doma in kdo jih največkrat obiskuje. To nas je zanimalo prav tako s stališča širjenja Medsebojni odno-
si so rdeča nit
človekovega učenja
vd užini. obzorij oziroma socialnega kroga. Ugotovili smo, da imajo doma obiske največkrat nekajkrat mesečno, ponovno pa jih obiskujejo $v$ največji meri sorodniki (glej tabelo 3 ). Za gimnazijce lahko rečemo, da imajo širši krog socialnih stikov, saj jih pogosteje kot dijake poklicnih šol obiščejo tudi prijatelji in sodelavci staršev.

\section{KOMUINIKACIJA V DRUŽINAH}

Medsebojni odnosi človeka izpopolnjujejo, kajti v okviru teh odnosov človek nenehno osebnostno raste in se uči, zato nas je zanimalo, kaj se dijaki pogovarjajo doma s starši in kaj s prijatelji. Č pogledamo graf 4, vidimo, da pri pogovorih doma med dijaki ni večjih razlik, kajti največkrat se doma pogovarjajo o navadnih stvareh, z izjemo nekaterih gimnazijcev, ki doma govorijo tudi o kulturnih dogodkih. Razlika med dijaki se pravzaprav pokaže šele pri pogovorih s prijatelji. $\breve{C} e$ pogledamo graf 5 , vidimo, da se gimnazijci s prijatelji pogovarjajo tudi o javnih in kulturnih dogodkih. Medtem ko se dijaki poklienih šol o teh temah večinoma ne pogovarjajo ne doma nes prijatelji. Tukaj vidimo vzorec, ki se prenaša s staršev na otroke. Prav tako se gimnazijci med seboj pogovarjajo o knjigah, kar se navezuje na njihove odgovore glede pogostega obiskovanja drugih knjižnic (študijske ...). Ker $\checkmark$ prostem času obiskujejo knjižnice, pomeni, da berejo knjige, ki jih zanimajo tudi izven šolskega programa, in se nato o prebranem tudi pogovarjajo, izmenjujejo mnenja. Dijaki poklicnih šol pa večinoma obiskujejo le šolsko knjižnico, kar pomeni, da berejo predvsem obvezno (domače) branje.

Zanimalo nas je tudi, ali se dijaki udeležijo pogovora doma, kadar imajo obiske. To vprašanje smo zastavili zato, da vidimo, koliko dijake zanimajo različne teme, ki so del vsakdanjih pogovorov odraslih ljudi in od katerih se lahko marsikaj naučijo. Ugotovili smo, da se 92 odstotkov gimnazijcev in le 56 odstotkov dijakov poklicnih šol pogovora $z$ obiski redno udeleži zato, ker jih tema zanima. Ker smo mnenja, da se pogovora radi udeležimo le takrat, ko naše mnenje upoštevajo kot enakovredno, niso presenetljivi odgovori, da 92 odstotkov gimnazijcev in 68 odstotkov dijakov poklicnih šol pri takšnih pogovorih upoštevajo kot enakovredne partnerje. V 
primeru, ko dijaki naletijo na neznano stvar ali besedo, pomoč večinoma poiščejo pri starših, so pa odgovori bolj razpršeni pri dijakih poklicnih šol (glej tabelo 4). Glede na izobrazbo staršev je mogoče, da ti ne poznajo vedno odgovora in se zato dijaki znajdejo drugače. Je pa tudi možno, da so dijaki poklicnih šol bolj nagnjeni $k$ temu, da pridejo stvari do dna in zato informacije iščejo na več straneh. Č gre za slednje, potem so odgovori spodbudni.

Za konec nas je zanimalo še, ali starši dijake spodbujajo $\mathrm{k}$ iskanju znanja izven šole. Kot vidimo na grafu 6, je pri starših gimnazijcev $v$ ospredju splošna razgledanost, svoje otroke

\section{Graf 4: O čem se pogovarjate doma}

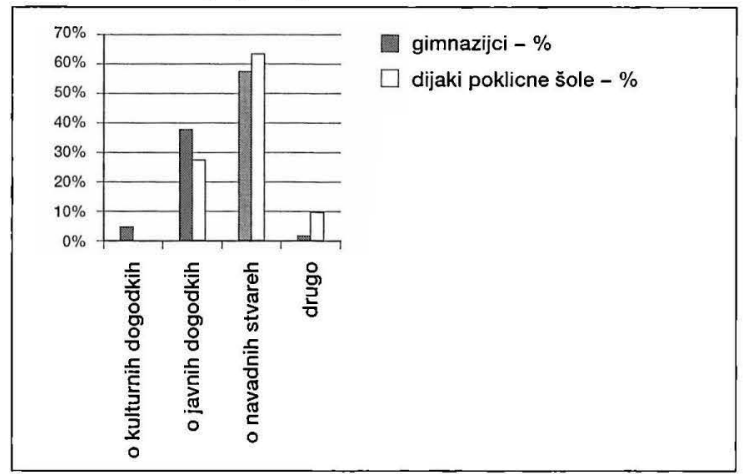

\section{Graf 5: 0 čem se pogovarjaš s prijatelii}

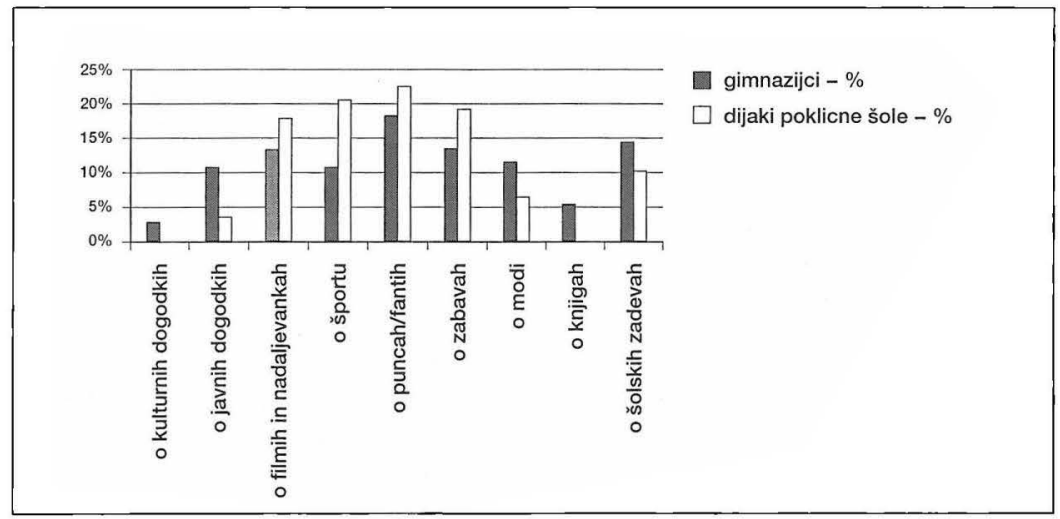

namreč spodbujajo $\mathrm{k}$ branju časopisov in knjig, pri starših dijakov poklicne šole pa je v ospredju zaposljivost, saj svoje otroke spodbujajo predvsem $\mathrm{k}$ pridobivanju dodatnega poklicnega znanja.

$\mathrm{Na}$ podlagi rezultatov raziskave lahko zaključimo, da razlike med gimnazijci in dijaki poklicnih šol niso več tako očitne, kot so bile ugotovljene pred leti $\mathrm{v}$ raziskavi $\mathrm{z}$ naslovom Razlike v neformalnem izobraževanju med posameznimi družinami (Ferletič, 2003, str. 40-48). Dejstvo, da je na nekate- rih področjih teh razlik vse manj, je več kot spodbudno, saj pomeni, da se tako starši kot dijaki vse bolj zavedajo pomena in priložnosti neformalnega izobraževanja.

\section{ZAKLJUČEK}

Kljub spodbudnim rezultatom je raziskava vseeno opozorila na pomembne vidike preživljanja prostega časa, na katere morajo biti starši še posebej pozorni. Gre za dejanja, 
Tabela 4: Kaj narediš, ko doma naletiš na neznano stvar (deleži v odstotkih)

\begin{tabular}{|l|c|c|c|c|c|c|c|c|}
\hline & nič & $\begin{array}{c}\text { vprašam } \\
\text { starša }\end{array}$ & $\begin{array}{c}\text { vprašam } \\
\text { brata/ } \\
\text { sestro }\end{array}$ & $\begin{array}{c}\text { vprašam } \\
\text { soseda }\end{array}$ & $\begin{array}{c}\text { poiščem } \\
\text { na } \\
\text { internetu }\end{array}$ & $\begin{array}{c}\text { poiščem } \\
\text { v knjigi/ } \\
\text { časopisu }\end{array}$ & drugo & skupaj \\
\hline gimnazijci & 12 & 80 & 0 & 0 & 0 & 8 & 0 & 100 \\
\hline dijaki pokl. šole & 16 & 64 & 8 & 0 & 8 & 4 & 0 & 100 \\
\hline
\end{tabular}

\section{Graf 6: Ali te starši spodbujajo k iskanju znanja}

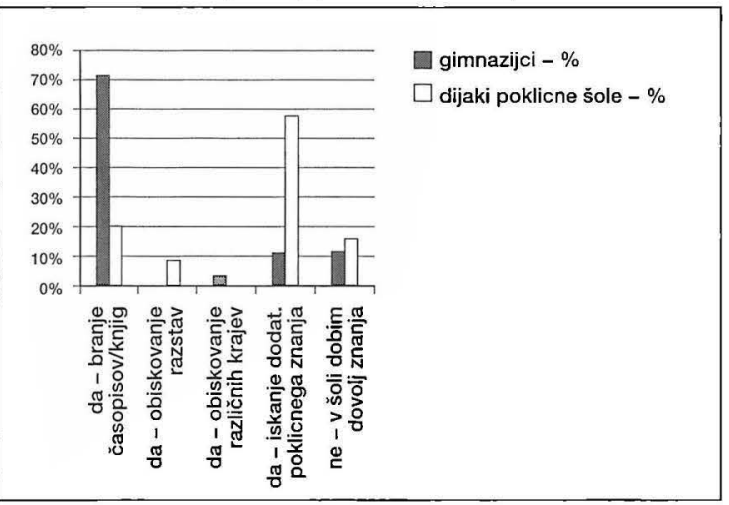

ki jim starši večinoma ne pripisujejo večjega pomena, $\mathrm{z}$ vidika neformalnega izobraževanja pa je njihov vpliv še kako pomemben. Gre predvsem za to, kaj se lahko otroci naučijo od svojih staršev in kako bodo to znanje potem uporabili v nadaljnjem življenju. Starši imajo velik vpliv na preživljanje prostega časa otrok s svojim zgledom. Če pogledamo samo televizijo kot množični medij. Nič ni sicer narobe, če po televiziji gledamo nadaljevanke in filme, je pa škoda, da tako vplivnega medija ne bi izkoristili tudi v bolj »uporabne« namene. Seveda ni dovolj, da otroke samo navajamo na gledanje poročil in raznih izobraževalnih, javnih, kulturnih oddaj, pomembno je, da jih naučimo kritičnega odnosa do medijev in selektivnega sprejemanja informacij. Kaj je torej pri preživljanju prostega časa pomembno? Pomembno je, da se starši za- vedajo svojega vpliva in svoja dejanja izbirajo premišljeno. Dijakom je namreč potrebno odkriti, da učenje ne poteka le $v$ šoli, na način, kot ga poznajo. Seznaniti jih je potrebno z neformalnim načinom izobraževanja $v$ družini, ki jih bo spremljal skozi celo življenje in spodbujal vseživljenjsko učenje.

\section{LITERATURA}

Cepin, M. (2004). Neformalno izobraževanje. Ljubljana: Društvo mladinski ceh.

Ferletič, K. (2003). Učeča se družina. Možnosti za neformalno izobraževanje $v$ družinah. Andragoška spoznanja, 1, str. 34-49.

Horvat, L. (1987). Razvojna psihologija. Ljubljana: DZS.

Jelenc, S. (1996). ABC Izobraževanja odraslih. Ljubljana: Andragoški center Republike Slovenije.

Jelenc, Z. (1991). Terminologija izobraževanja odraslih. Ljubljana: Pedagoški inštitut.

Jelenc, Z., Drofenik, O. (1994). Temeljno izobraževanje odraslih. Neformalno izobraževanje odraslih: raziskovalni porocili. Ljubljana: Andragoški center Slovenije.

Ličen, N. (1996). Družina kot učna izkušnja. Andragoška spoznanja, 1, str. 5-12.

Ličen, N. (2000). Bivati v družini - učiti se v družini. Družina kot učno okolje. Andragoška spoznanja, 4, str. 6-15.

Ličen, N. (1999). Izobraževanje odraslih za življenje v družinski skupnosti. Doktorska disertacija. Ljubljana: Filozofska fakulteta.

Memorandum o vseživljenjskem učenju (2000). Komisija Evropske skupnosti.

Mrgole, A. (2003). Kam z mularijo? Načela kakovosti neformalnega dela z mladimi. Ljubljana. Ministrstvo za šolstvo, znanost in šport, Urad RS za šolstvo in Aristej. Muršak, J. (2002). Pojmovni slovar za področje poklicnega in strokovnega izobraževanja. Ljubljana: Ministrstvo za šolstvo, znanost in šport, Urad RS za šolstvo, 
Center RS za poklicno izobraževanje.

Ule, M. (1995). Pri(pre)hodnost mladine. Ljubljana: DZS in Ministrstvo za šolstyo, znanost in §port.

Vseživljenjsko učenje: prispevek izobraževalnih sistemov v državah članicah Evropske unije: rezultati študije Eurydice (2002). Ljubljana: Ministrstvo za Solstvo, znanost in šport. 